\title{
Nutrient uptake and dry matter yield in the 'Gunung' yam (Dioscorea alata) grown on an Ultisol without vine support ${ }^{1,2}$
}

\author{
Héber Irizarry ${ }^{3}$, Ricardo Goenaga 4 and Ulises Chardón \\ ABSTRACT
}

Two experiments were established 1 May through 1 December 1991 and 1992 to determine the monthly nutrient uptake and dry matter production of the 'Gunung' yam (Dioscorea alata) grown on an Ultisol. During the first year the plants were fertilized with $0 ; 667 ; 1,333 ; 2,000$ and $2,667 \mathrm{~kg} / \mathrm{ha}$ of a 15-515-5 ( $\mathrm{N}, \mathrm{P}_{2} \mathrm{O}_{5}, \mathrm{~K}_{2} \mathrm{O}$ and $\left.\mathrm{MgO}\right)$ fertilizer supplemented with a minor element mixture. No fertilizer was applied the second year. Biomass harvests were conducted at 2, 3, 4, 5, 6 and 7 months after planting. At each harvest, the plants were dug-up and separated into leaf-laminas, vine and petioles, roots and tubers. Fresh and oven-dry weights of the plant components were determined and samples from each were analyzed for $\mathrm{N}, \mathrm{P}, \mathrm{K}, \mathrm{Ca}$ and $\mathrm{Mg}$. Regardless of the year, tuber dry matter yield was not significantly affected by the fertilizer treatment. Maximum nutrient uptakes were $214 \mathrm{~kg} / \mathrm{ha}$ of $\mathrm{N}, 19$ $\mathrm{kg} / \mathrm{ha}$ of $P, 223 \mathrm{~kg} / \mathrm{ha}$ of $K, 95 \mathrm{~kg} / \mathrm{ha}$ of $\mathrm{Ca}$ and $9 \mathrm{~kg} / \mathrm{ha}$ of $\mathrm{Mg}$. Nitrogen, $\mathrm{K}$ and Ca uptake peaks occurred about five months after planting. Maximum dry matter production was $11,303 \mathrm{~kg} / \mathrm{ha}, 8,672 \mathrm{~kg} / \mathrm{ha}$ of which was tuber dry weight. The dry matter production peak occurred at the completion of the 7month cropping cycle. The plants utilized $24.7 \mathrm{~kg} / \mathrm{ha}$ of $\mathrm{N}, 2.2 \mathrm{~kg} / \mathrm{ha}$ of $P, 25.7$ $\mathrm{kg} / \mathrm{ha}$ of $\mathrm{K}, 11.0 \mathrm{~kg} / \mathrm{ha}$ of $\mathrm{Ca}$ and $1.0 \mathrm{~kg} / \mathrm{ha}$ of $\mathrm{Mg}$, for every $1,000 \mathrm{~kg} / \mathrm{ha}$ of edible dry matter produced.

Key words: yam, nutrient uptake, yield

\section{RESUMEN}

Extracción de nutrimentos y rendimiento de materia seca en el ñame cv 'Gunung' (Dioscorea alata) sembrado sin soportes en un suelo Ultisol

Se establecieron dos experimentos en las mismas parcelas desde 1 de mayo a 1 de diciembre de 1991 y 1992 para determinar la extracción mensual de nutrimentos y producción de materia seca en el ñame 'Gunung'. En el primer año las plantas fueron abonadas a razón de $0 ; 667 ; 1,333 ; 2,000$ y $2,667 \mathrm{~kg} / \mathrm{ha}$ con un fertilizante $15-5-15-5\left(\mathrm{~N}, \mathrm{P}_{2} \mathrm{O}_{5}, \mathrm{~K}_{2} \mathrm{O}\right.$ y $\left.\mathrm{MgO}\right)$ suplementado con elementos menores. El segundo año no se aplicó fertilizante. Se efec-

'Manuscript submitted to Editorial Board 16 November 1994.

2This paper covers work carried out cooperatively between the Agricultural Research Service-USDA and the Agricultural Experiment Station, University of Puerto Rico (AESUPR), Rio Piedras, Puerto Rico. The authors are grateful to Nicolás Diaz and Javier Fuentes, Agricultural Research Technicians for their assistance in carrying out the field work.

Research Horticulturist, Tropical Agriculture Research Station, P.O. Box 70, Mayagüez, Puerto Rico 00681.

-Research Plant Physiologist, Tropical Agriculture Research Station.

${ }^{5}$ Chemist, Tropical Agriculture Research Station. 
tuaron seis cosechas de biomasa a los $2,3,4,5,6$ y 7 meses después de la siembra. En cada cosecha las plantas fueron excavadas y separadas en láminas de hojas, tallos y peciolos, raices y tubérculos. Se determinó el peso húmedo y seco de los componentes de la planta y se obtuvieron muestras de tejido. Luego estas muestras se analizaron para determinar su contenido de $\mathrm{N}, \mathrm{P}, \mathrm{K}, \mathrm{Ca}$ y $\mathrm{Mg}$. Independientemente del año, los tratamientos de fertilizantes no afectaron significativemente el rendimiento en peso seco de los tubérculos mercadeables. La extracción máxima de nutrimentos fue $214 \mathrm{~kg} /$ ha de $\mathrm{N}, 19 \mathrm{~kg} / \mathrm{ha}$ de $P, 223 \mathrm{~kg} / \mathrm{ha}$ de $\mathrm{K}, 95 \mathrm{~kg} / \mathrm{ha}$ de Ca y $9 \mathrm{~kg} / \mathrm{ha}$ de $\mathrm{Mg}$. La producción máxima de materia seca fue $11,303 \mathrm{~kg} / \mathrm{ha}$ de los cuales $8,672 \mathrm{~kg} /$ ha se acumularon en los tubérculos mercadeables. La extracción máxima de N, K, y Ca ocurrió a los cinco meses después de la siembra. La producción máxima de materia seca fue a los siete meses. Las plantas del ñame utilizaron $24.7 \mathrm{~kg} / \mathrm{ha}$ de $\mathrm{N}, 2.2 \mathrm{~kg} / \mathrm{ha}$ de $P, 25.7 \mathrm{~kg} / \mathrm{ha}$ de $K, 11.0 \mathrm{~kg} / \mathrm{ha}$ de Ca $y$ $1.0 \mathrm{~kg} / \mathrm{ha}$ de $\mathrm{Mg}$ por cada $1,000 \mathrm{~kg} / \mathrm{ha}$ de materia seca comestible producida.

\section{INTRODUCTION}

Yam production in Puerto Rico declined from 15,455 t in 1980 to $10,545 \mathrm{t}$ in 1991. During the same period, the crop farm gate-value increased from $\$ 8.0$ to $\$ 8.7$ million, but yearly imports were necessary to satisfy the local demand (Ortiz-López, 1992).

Constraints associated with the downward trend in yam production are low yields, pests and diseases, and high input costs. Inorganic fertilization is the third most costly input, after the construction of woodwire trellises for vine support and crop harvest (Anonymous, 1984).

A previous study showed that the local yam $D$. rotundata cv Habanero grown under intensive management on an upland Ultisol removed a total of $189 \mathrm{~kg} / \mathrm{ha}$ of N, $25 \mathrm{~kg} / \mathrm{ha}$ of P, $215 \mathrm{~kg} / \mathrm{ha}$ of K, $91 \mathrm{~kg} / \mathrm{ha}$ of Ca and $31 \mathrm{~kg} / \mathrm{ha}$ of $\mathrm{Mg}$. Yields were $18,000 \mathrm{~kg} / \mathrm{ha}$ of edible dry matter for an 8-month cropping cycle (Irizarry et al., 1985). Of the total uptake, the plants utilized $10.5 \mathrm{~kg} / \mathrm{ha}$ of $\mathrm{N}, 1.4 \mathrm{~kg} / \mathrm{ha}$ of $\mathrm{P}, 11.0 \mathrm{~kg} / \mathrm{ha}$ of $\mathrm{K}, 5.1$ $\mathrm{kg} / \mathrm{ha}$ of $\mathrm{Ca}$ and $2.0 \mathrm{~kg} / \mathrm{ha}$ of $\mathrm{Mg}$ for every $1,000 \mathrm{~kg} / \mathrm{ha}$ of tuber dry matter produced. In Nigeria, the white yam 'Atoja' (D. rotundata) removed from unfertilized plots a total of 135,9 and $78 \mathrm{~kg} /$ ha of $\mathrm{N}, \mathrm{P}, \mathrm{K}$, respectively. At the completion of the cropping cycle, yields were $8,968 \mathrm{~kg} / \mathrm{ha}$ of edible dry matter (Sobulo, 1972). Plants utilized $15.0 \mathrm{~kg} / \mathrm{ha}$ of $\mathrm{N}, 1.0$ $\mathrm{kg} / \mathrm{ha}$ of $\mathrm{P}$ and $8.7 \mathrm{~kg} / \mathrm{ha}$ of $\mathrm{K}$ for every $1,000 \mathrm{~kg} / \mathrm{ha}$ of edible dry matter yielded. Of the total nutrients removed by the yam plant the quantities that are taken away from the field with the tuber harvest and the amount that recycles to the soil from plant residues depend on the dry matter weight, the concentration of each nutrient in the various plant components and the species (Ferguson and Haynes, 1970; Obigbesan and Agboola, 1978).

In this study we determined the monthly and total nutrient uptake and dry matter production of the D. alata cv Gunung yam grown on an Ultisol without vine support during two successive years. 


\section{MATERLALS AND METHODS}

Two experiments were established on the same site 1 May through 1 December 1991 and 1992 at the Corozal substation of the AES-UPR. The substation is located in the north-central region of Puerto Rico at an elevation of about $200 \mathrm{~m}$. Throughout the experiments, minimum and maximum mean monthly temperatures were 18.3 and $30.9^{\circ} \mathrm{C}$, respectively, with variations of plus or minus 1.9 to $3.5^{\circ} \mathrm{C}$. Average monthly rainfall was $151.7 \mathrm{~mm}$ and pan evaporation $120.5 \mathrm{~mm}$. During the months of June, August and September 1991, and June and October 1992, evaporation exceeded rainfall.

The soil is a Corozal clay (Aquic Tropudults, clayey, mixed isohyperthermic). Table 1 presents chemical properties of the soil. The field was plowed twice, and ground limestone was applied at the rate of 4.5 tha before the establishment of the 1991 experiment.

Tubers of the Gunung cultivar were sectioned into pieces weighing 112 to $140 \mathrm{~g}$. Pregerminated sections were planted without vine support in flat rows spaced $0.91 \mathrm{~m}$ between rows and $0.30 \mathrm{~m}$ apart in the row, for a density of 35,830 plants per hectare.

Weeds were suppressed with a preemergence application of Ametryne $^{6}$ at the rate of $4.5 \mathrm{~kg} / \mathrm{ha}$. No other pesticide application was necessary for normal crop development.

Five fertilizer treatments, $0 ; 667 ; 1,333 ; 2,000$ and $2,667 \mathrm{~kg} / \mathrm{ha}$ of a 15-5-15-5 ( $\mathrm{N}, \mathrm{P}_{2} \mathrm{O}_{5}, \mathrm{~K}_{2} \mathrm{O}$ and $\left.\mathrm{MgO}\right)$ mixture, and six biomass harvest dates (July through December, 1991 and 1992) were evaluated. The fertilizer mixture was supplemented with minor elements at the rate of $25.4 \mathrm{~kg} / \mathrm{t}$. Fertilizer treatments were applied in a single sidedressing application 50 days after the 1991 planting. No fertilizer was applied during the second year. The experimental design was a split-plot in space and time with four replications. The main plot (fertilizer rates) covered an area of 1.8 by $22.2 \mathrm{~m}$, and accommodated six subplots of 1.8 by $3.7 \mathrm{~m}$ each, representing the biomass harvests without rerandomization the second year. Alleys $1.8 \mathrm{~m}$ wide separated the main plots to prevent overlapping of fertilizer and tangling of vines between adjacent plots.

Biomass harvest began 1 July and continued the first day of each month through 1 December 1991 and 1992. In the 1991 experiment, 24 plants from each subplot were harvested. Because of the high labor requirements during each biomass harvest, in 1992 the subplot size was reduced to 12 plants.

\footnotetext{
"Trade names in this publication are used only to provide specific information. Mention of a trade name does not constitute a warranty of materials by the USDA-ARS or the UPR-AES, nor is this mention a statement of preference over other materials.
} 
TABLE 1.-Soil chemical properties obtained in a 20.cm depth Corozal clay before the establishment of the 1991 and 1992 experiments.

\begin{tabular}{|c|c|c|c|c|c|c|}
\hline \multirow[b]{2}{*}{ Year } & \multirow[b]{2}{*}{ Soll pH } & \multirow[b]{2}{*}{ Total N } & \multirow[b]{2}{*}{ Available P } & \multicolumn{3}{|c|}{ Exchangeable } \\
\hline & & & & K & $\mathrm{Ca}$ & $\mathrm{Mg}$ \\
\hline & & $\%$ & $\ldots . . .6$ & $\cdots$ & $\ldots$ & \\
\hline 1991 & 4.70 & 0.18 & 2.32 & 247 & 1,090 & 83 \\
\hline \multirow[t]{5}{*}{1992} & 4.98 & 0.19 & 2.95 & 242 & 1,571 & 76 \\
\hline & 4.83 & 0.19 & 3.32 & 197 & 1,536 & 55 \\
\hline & 4.99 & 0.22 & 3.96 & 237 & 1,673 & 67 \\
\hline & 4.89 & 0.21 & 4.47 & 210 & 1,468 & 63 \\
\hline & 4.72 & 0.22 & 4.29 & 249 & 1,482 & 64 \\
\hline
\end{tabular}

'The 1991 values represent the composite of 20 soil samples covering the total experimental area. The 1992 values are the composite of 120 soil samples representing 5 fertilizer rates $(0 ; 667 ; 1,333 ; 2,000$ and $2,667 \mathrm{~kg} / \mathrm{ha}$ ) applied during the 1991 experiment, and replicated four times.

At harvest, all plants from each subplot were dug up and separated into leaf-laminas, vine and petioles, roots, and tubers. Fresh and ovendry weights of plant components were determined. Samples from each component were ground, sifted through a 20 -mesh screen and analyzed for N, P, K, Ca and Mg. Nitrogen was determined by the Micro-Kjeldahl method, $\mathrm{P}$ colorimetrically, $\mathrm{K}$ by flame photometry, and $\mathrm{Ca}$ and $\mathrm{Mg}$ by the Versenate method after digestion with nitric-perchloric acid.

Nutrient uptake was calculated by using the product of the dry matter weight and the nutrient concentration in plant components. After the completion of the 7-month cropping cycle, the tuber dry weight was subjected to an analysis of variance, and the nutrient uptake data to a regression analysis. Only coefficients significant at $\mathrm{P} \leq 0.05$ and best fit curves were retained in the models.

\section{RESULTS AND DISCUSSION}

A significant harvest date $\times$ year interaction was observed for tuber dry weight (Table 2). During the first three biomass harvests, tuber dry weight was higher in the 1991 experiment. Thereafter, tuber dry weight was consistently higher in the 1992 experiment. However, at the termination of the 7-month cropping cycle there was no significant difference between years for final tuber dry weight (data not shown).

Regardless of the year, tuber dry weight was not significantly affected by fertilizer treatments (Table 2). On the average, for all fertilizer treatments and year, the $D$. alata $\mathrm{cv}$ Gunung yam produced 
TABLE 2.-Analysis of variance for the effect of fertilizer rates, harvest dates and years on tuber dry zeight of the 'Gunung' yam.

\begin{tabular}{lrr}
\hline Source & Degrees of freedom & Mean square \\
\hline Replication & 3 & 871,299 \\
Fertilizer rate & 4 & $1,667,032$ \\
Error a & 12 & 577,446 \\
Harvest date & 5 & $485,840,265$ \\
Fertilizer rate $\times$ harvest date & 20 & 941,218 \\
Error b & 75 & 957,773 \\
Year & 1 & $3,261,253$ \\
Error c & 3 & $1,044,613$ \\
Fertilizer rate $\times$ year & 4 & $1,276,728$ \\
Error d & 12 & $1,020,397$ \\
Harvest date $\times$ year & 5 & $1,529,785$ \\
Fertilizer rate $\times$ harvest date $\times$ year & 20 & 518,723 \\
Error e & 75 & 639,788 \\
\hline
\end{tabular}

iSignificant at the 0.05 probability level.

$8,672 \mathrm{~kg} / \mathrm{ha}$ of edible dry matter equivalent to $58,764 \mathrm{~kg} / \mathrm{ha}$ of fresh marketable tuber weight during the 7-month cropping cycle. The low edible dry matter to fresh tuber weight ratio of $1: 6.8$ was caused by the low dry matter concentration of the tubers. Seven months after planting, the tuber dry matter concentration was only $14.9 \%$, about half of what has been found in the D. rotundata cv Habanero (Acevedo-Borrero, 1988; Irizarry and Rivera, 1985).

The lack of yield response to fertilization can be attributed in part to adequate residual quantities of $\mathrm{N}, \mathrm{K}$ and $\mathrm{Mg}$ in the soil (Table 1). Other factors are the proven nutrient supplying capacity of the local upland Ultisols (Abruña et al., 1976; Vicente-Chandler et al., 1974) and the ability of the D. alata yams to thrive on low fertility soils (Norman et al., 1984). Still other possible factors are the adaptability of the 'Gunung' yam to grow with vines creeping on the soil (Irizarry and Rivera, 1993), and the inherited ability of the cultivar to develop a profuse root system. Throughout the harvest the 'Gunung' yam exhibited an extensive, healthy root system free of nematodes.

Since fertilizer treatments and years did not have a significant effect on tuber dry weight (Table 2), the discussion that follows and data presented are the mean of five fertilizer treatments and two cropping years.

Uptakes of $\mathrm{N}, \mathrm{K}$ and $\mathrm{Ca}$ increased rapidly with plant age until about five months after planting and then declined (Figure 1). Phosphorus and $\mathrm{Mg}$ uptakes were low and remained practically unchanged during 


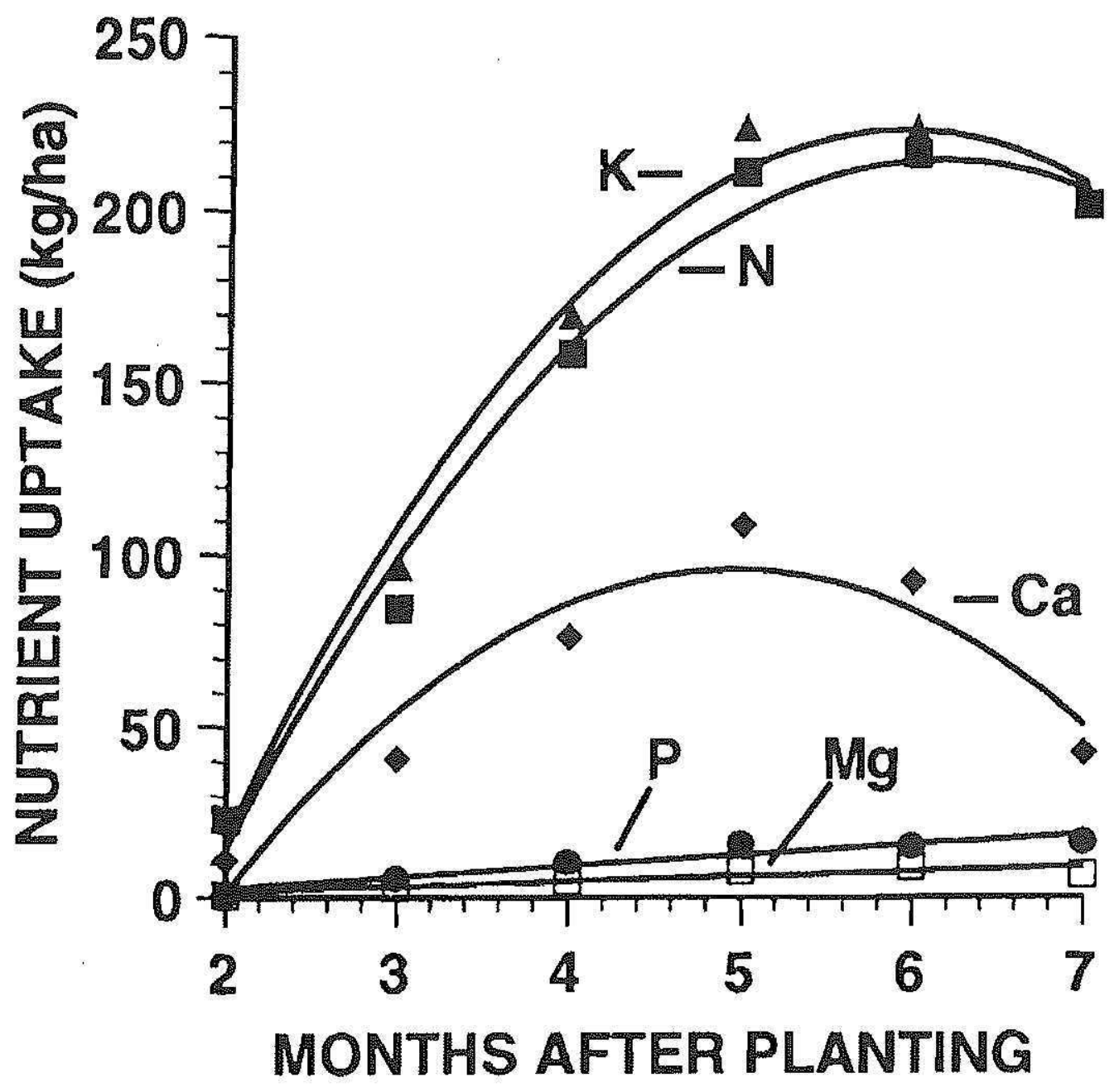

FIGURE 1. Cumulative nutrient uptake in the 'Gunung' yam as influenced by plant age. Regression equations for:
$N \quad Y=-225.90+143.62(x)-11.71(x)^{2}$
$r^{\prime \prime}=0.99$
$Y=-244.77+157.91(x)-13.33(x)^{2}$
$r^{2}=0.99$
$\mathrm{Ca} \quad Y=-168.14+106.41(\mathrm{x})-10.74(\mathrm{x})^{2}$
$r^{2}=0.90$
$\mathrm{P} \quad \mathrm{Y}=-3.01+3.21(\mathrm{x})$
$\mathrm{Mg} \quad \mathrm{Y}=-0.78+1.40(\mathrm{x})$
$1^{2}=0.79$
$1^{2}=0.73$

the growth cycle. Maximum nutrient uptakes were $214 \mathrm{~kg} / \mathrm{ha}$ of $\mathrm{N}, 19$ $\mathrm{kg} / \mathrm{ha}$ of P, $223 \mathrm{~kg} / \mathrm{ha}$ of $\mathrm{K}, 95 \mathrm{~kg} / \mathrm{ha}$ of Ca and $9 \mathrm{~kg} / \mathrm{ha}$ of $\mathrm{Mg}$ (Figure 1 ).

Maximum dry matter production was $11,303 \mathrm{~kg} / \mathrm{ha}$, and occurred at the completion of the 7-month cropping cycle (Table 3). Of this amount $8,672 \mathrm{~kg} / \mathrm{ha}(76.7 \%$ ) was tuber dry matter (Table 4). 'Gunung' plants took up $24.7 \mathrm{~kg} / \mathrm{ha}$ of N, $2.2 \mathrm{~kg} / \mathrm{ha}$ of P, $25.7 \mathrm{~kg} / \mathrm{ha}$ of $\mathrm{K}, 11.0 \mathrm{~kg} / \mathrm{ha}$ of Ca and $1.0 \mathrm{~kg} / \mathrm{ha}$ of $\mathrm{Mg}$ for the production of every $1,000 \mathrm{~kg} / \mathrm{ha}$ of edible dry matter (Table 4). These $\mathrm{N}, \mathrm{K}$, and Ca quantities are more than twice what the $D$, rotundata cv Habanero plants utilized to produce a similar 
TABLE 3.-Mean nutrient contents in the various components of the 'Gunung' plant and total ary matter produced at different stages of growth.

\begin{tabular}{|c|c|c|c|c|c|c|c|c|c|c|c|c|c|c|c|c|c|c|c|c|c|}
\hline \multirow{2}{*}{$\begin{array}{l}\text { Months } \\
\text { after } \\
\text { planting }\end{array}$} & \multicolumn{5}{|c|}{ Leaf-laminas } & \multicolumn{5}{|c|}{ Vine and petioles } & \multicolumn{5}{|c|}{ Routs } & \multicolumn{5}{|c|}{ Tubers } & \multirow{2}{*}{$\begin{array}{l}\text { Total dry } \\
\text { matter }\end{array}$} \\
\hline & $N$ & $\mathrm{P}$ & $K$ & $\mathrm{Ca}$ & $\mathrm{Mg}$ & $\mathrm{N}$ & $\mathrm{P}$ & $\mathrm{K}$ & $\mathrm{Ca}$ & $\mathrm{Mg}$ & $\mathrm{N}$ & $\mathrm{P}$ & $\mathrm{K}$ & $\mathrm{Ca}$ & Mig & $N$ & $\mathrm{P}$ & $\mathrm{K}$ & $\mathrm{Ca}$ & $\mathrm{Mg}$ & \\
\hline 2 & 13.63 & 0.69 & 10.70 & 8.96 & 0.50 & 5.11 & 0.49 & 8.27 & 1.32 & 0.27 & 0.66 & 0.05 & 0.85 & 0.17 & 0.05 & 3.81 & 0.30 & 5.43 & 0.83 & 0.12 & 828.76 \\
\hline 3 & 57.84 & 3.11 & 51.95 & 33.86 & 1.9 .3 & 20.53 & 2.17 & 36.29 & 5.70 & 1.04 & 1.46 & 0.13 & 3.02 & 0,41 & 0.15 & 4.74 & 0.32 & 5.43 & 1.02 & 0.14 & $3,059.02$ \\
\hline 4 & 103.69 & 5.30 & 90.42 & 59.41 & 2.97 & 38.37 & 3.76 & 60.90 & 15.08 & 1.41 & 2.44 & 0.22 & 4.10 & 0.69 & 0.23 & 13.75 & 1.35 & 13.93 & 1.24 & 0.47 & $6,449.06$ \\
\hline 6 & 74.27 & 3.98 & 56.22 & 62.24 & 2.78 & 28.95 & 2.38 & 45.99 & 23.91 & 1.45 & 1.15 & 0.07 & 1.02 & 0.48 & 0.15 & 111.76 & 8.82 & 120.20 & 5.47 & 4.43 & 11.257 .23 \\
\hline 7 & 19.63 & 1.17 & 13.02 & 21.57 & 0.87 & 16.36 & 1.31 & 24.26 & 16.26 & 0.85 & 0.44 & 0.03 & 0.32 & 0.22 & 0.06 & 164.97 & 14.11 & 166.59 & 4.46 & 4.96 & $11,302.64$ \\
\hline
\end{tabular}


TABLE 4.-Summary of the mean nutrient contents and dry matter produced in the various components of the 'Gunung' plant at the completion of the 7-month cropping cycle.

\begin{tabular}{|c|c|c|c|c|c|c|}
\hline \multirow[b]{2}{*}{ Plant component } & \multicolumn{5}{|c|}{ Nutrient } & \multirow[b]{2}{*}{ Dry matter } \\
\hline & $N$ & $\mathrm{P}$ & K & $\mathrm{Ca}$ & $\mathrm{Mg}$ & \\
\hline & $\ldots \ldots$ & & ..... & $-\mathrm{kg} / \mathrm{h}$ & a. - & $2-2$ \\
\hline Roots & 0.4 & 0.1 & 0.3 & 0.2 & 0.1 & 49.3 \\
\hline Leaf-laminas & 19.6 & 1.2 & 13.0 & 21,5 & 0.9 & 774.6 \\
\hline Vine and petioles & 16.4 & 1.3 & 24.3 & 16.3 & 0.8 & $1,807.0$ \\
\hline $\begin{array}{l}\text { Lost during early senescence of leaves } \\
\text { and vines }\end{array}$ & 12.6 & 2.3 & 18.8 & 52.5 & 2.3 & - \\
\hline Tubers & 165.0 & 14.1 & 166.6 & 4.5 & 4.9 & $8,671.7$ \\
\hline Total & 214.0 & 19.0 & 223.0 & 95.0 & 9.0 & $11,302.6$ \\
\hline
\end{tabular}

amount of edible dry matter in an Ultisol (Irizarry and Rivera, 1985). Most of the N, P, K and Mg taken up by 'Gunung' plants was stored in the tubers and taken away from the field during mature tuber harvest. At the completion of the 7-month cropping cycle the mature tubers contained $19.2 \mathrm{~kg} / \mathrm{ha}$ of $\mathrm{N}, 1.6 \mathrm{~kg} / \mathrm{ha}$ of $\mathrm{P}, 19.2 \mathrm{~kg} / \mathrm{ha}$ of $\mathrm{K}, 0.5 \mathrm{~kg} / \mathrm{ha}$ of $\mathrm{Ca}$ and $0.6 \mathrm{~kg} / \mathrm{ha}$ of $\mathrm{Mg}$ for every $1,000 \mathrm{~kg} / \mathrm{ha}$ of tuber dry weight harvested (Table 4). The content of $\mathrm{N}$ and $\mathrm{K}$ in the tubers was about $45 \%$ greater than the amounts found in similar studies with D. rotundata (AcevedoBorrero, 1988; Irizarry and Rivera, 1993; Obigbesan and Agboola, 1978; Sobulo, 1972). Recycled nutrients, equivalent to $49 \mathrm{~kg} / \mathrm{ha}$ of N, 5 $\mathrm{kg} / \mathrm{ha}$ of $\mathrm{P}, 56 \mathrm{~kg} / \mathrm{ha}$ of $\mathrm{K}, 90 \mathrm{~kg} / \mathrm{ha}$ of $\mathrm{Ca}$ and $4 \mathrm{~kg} / \mathrm{ha}$ of $\mathrm{Mg}$, were returned to the soil with the production of $2,631 \mathrm{~kg} / \mathrm{ha}$ of leaves, vines and roots dry matter (Table 4 ).

During the first five months after planting, the most active sink for nutrients were the leaf-laminas, and vine and petioles (Table 3). Thereafter, these components exhibited a drastic nutrient decline as shoot senescence was initiated, and the tubers became the most active sinks of $\mathrm{N}, \mathrm{P}, \mathrm{K}$ and $\mathrm{Mg}$. However, throughout the cropping cycle the shoot components remained the most active sink for Ca.

Except for Ca in the shoot, nutrient concentration in the other plant components decreased with plant age (Table 5). Considering this factor, and that peak dry matter accumulation in the shoot occurred about five months after planting (data not shown), we inferred that the most appropriate time to determine the nutritional status of the 'Gunung' plant is between three to four months after planting, before the plant reaches maximum shoot growth. At this stage, the nutrient concentration in the leaf-laminas was: $\mathrm{N}=3.42-3.08, \mathrm{P}=0.19-0.16, \mathrm{~K}=3.05-2.70$, 
TABLE 5.-Nutrient concentration in the various components of the 'Gunung' plant at different stages of growth

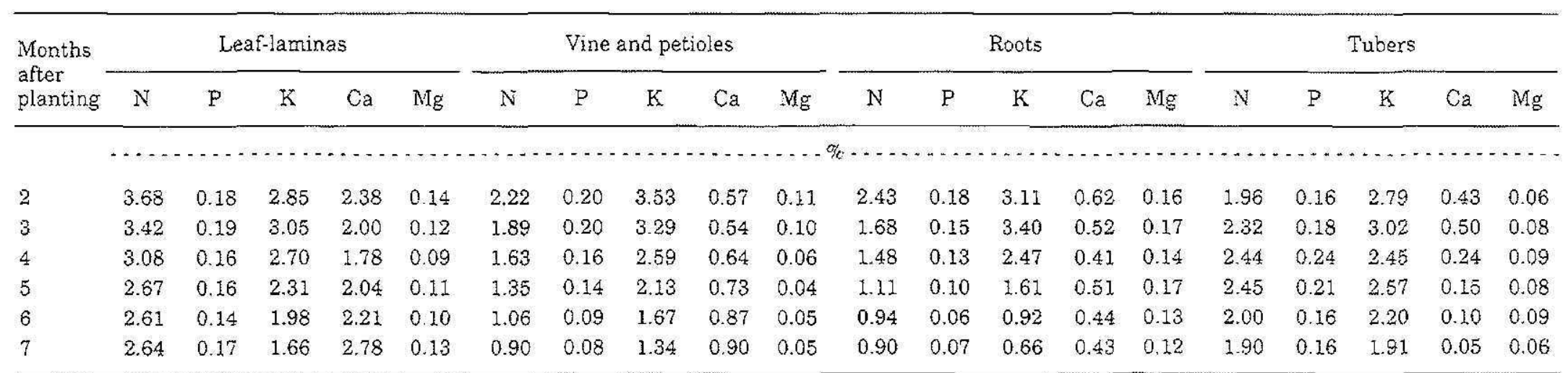


$\mathrm{Ca}=2.00-1.78$ and $\mathrm{Mg}=0.12-0.09 \%$. At all plant ages, the $\mathrm{N}$ concentration was always higher, and $\mathrm{Mg}$ content lower, in leaves of $D$. alata $\mathrm{cv}$ Gunung than in leaves of $D$. rotundata cv Habanero (Irizarry and Rivera, 1985).

\section{LITERATURE CITED}

Abruña, F, J. Vicente-Chandler, J. Figarella and S. Silva, 1976. Potassium supplying power of the major Ultisols and Oxisols of Puerto Rico. J. Agric. Univ. P.R. 60(1):4560.

Acevedo-Borrero, E, 1988. Efectos de niveles de fósforo y potasio sobre el rendimiento del name Dioscorea rotundata, Poir en un Oxisol bajo cultivo intensivo. Tésis, Depto. Agronomía y Suelos, Colegio de Ciencias Agrícolas, Univ. de P.R.

Anonymous, 1984. Conjunto tecnológico: Cosechas farináceas. Publ. 101, 2da. ed. Esta. Exp. Agric. Univ. P.R.

Irizarry, H. and E. Rivera, 1993. Yield of two yam (Dioscorea alata) cultivars with three planting dates and two planting systems. J. Agric. Univ. P.R. 77(3-4):161-166.

Irizarry, H. and E. Rivera, 1985. Nutrient uptake and dry matter production by intensively managed yams grown in an Ultisol. J. Agric. Univ. P.R. 69(1):1-9.

Ferguson, T. U. and P. H. Haynes, 1970. The response of yams Dioscorea spp. to nitrogen, phosphorus, potassium, and organic fertilizers. Proc. 2nd Inter. Symposium on Trop. Root and Tuber Crops, Honolulu, Hawaii, p. 93-96.

Norman, M. J. T., C. J. Pearson and P. G. E. Searle, 1984. Yams (Dioscorea spp.). The ecology of tropical food crops. Cambridge Univ. Press, Cambridge, Great Britain.

Obigbesan, G. O. and A. A. Agboola, 1978. Uptake and distribution of nutrients by yams (Dioscorea spp.) in Western Nigeria. Exp. Agric. 14:349-355.

Oxtiz-López, J., 1992. Farináceas: Situación y Perspectivas - Empresas Agrícolas de Puerto Rico 1989-90, 1990-91. Esta. Exp. Agric. Univ. P.R.

Sobulo, R. A., 1972. Studies on white yam (Dioscorea rotundata) M. Changes in nutrient content with age. Exp. Agric. 8:107-115.

Vicente-Chandler, J., F. Abruña, R. Caro-Costas, J. Figarella, S. Silva and R. W. Pearson, 1974. Intensive grassland management in the humid tropics of Puerto Rico. Bull. 233, Agric. Exp. Sta., Univ. P.R. 